\title{
THE CHANGING ROLE OF URBAN HERITAGE: GOVERNANCE AND STAKEHOLDERS' PERCEPTIONS IN TURKEY AND THE UNITED ARAB EMIRATES
}

\author{
Ayşe Ege YILDIRIM*
}

Received: 19.09.2013; Final Text: 27.02.2015

Keywords: Stakeholders; urban conservation; globalization; Turkey; United Arab Emirates.
* A. Ege Yildirim Heritage Planning, İstanbul, TURKEY.

\section{INTRODUCTION}

\section{Background of the Study}

The concept of heritage conservation has constantly evolved since the birth of this modern notion in the 19th century. Around the middle of the 20th century, heritage began to be understood in an urbanistic sense and to feature in planning discourse, transcending the curatorial framework of single monuments and museums. This still remains an important and relevant conceptual milestone, as its implications continue to be addressed today. The conflicts between the philosophical aspects of urban heritage, related to its importance as a source of cultural identity, and the practical aspects, related to the realities of real estate economics, have as yet not been fully resolved. International principles and professional standards of heritage conservation have spread around the world, but their interpretation in each cultural context and the levels of practice that are attained still differ from country to country. This is both a challenge in terms of safeguarding the values that heritage presents, and an opportunity in terms of the multiple alternatives for preservation approaches offered by the diversity of the world's cultures. The understanding of how approaches can be customized also averts the dangers of importing foreign models to places far from their original source without regard for the particular needs of local contexts.

Many of the underlying dynamics determining the level of understanding of, and thus the role attributed to heritage in the life of today's cities, are cultural, which implies they are contingent on the value systems, attitudes and behaviors of the stakeholders taking part in the urban discourse. This idea has been explored here within two cultural contexts, those of Turkey and the United Arab Emirates, where the author had a chance to observe these dynamics in action. In Turkey, these observations are based particularly on the author's doctoral dissertation titled Urban Conservation Projects and Governance prepared between 2008-2011, and in the UAE, 
on the author's experience in the heritage protection authority of Abu Dhabi Emirate in 2008-2012. In both contexts, it has been possible to observe certain recurring patterns and an evolution in the perceptions of stakeholders regarding the urban heritage, albeit set in different social and political circumstances. The rationale for this comparative cross-cultural analysis lies in the unique opportunity to examine the role of heritage for stakeholders in both contexts through empirical research, as they were simultaneously experienced first-hand by the same individual. The close familiarity with the stakeholders, the project processes and their cultural milieus, through observation and direct involvement, enabled a detailed and qualitative examination of behavior and decision-making, and an important insight into the underlying attitudes and value systems.

\section{Active and Productive: Evolving Role of Heritage}

The new understanding of heritage as an urbanistic force that has a symbiotic relationship with development is advocated by various researchers in the field, and increasingly gaining recognition in related industries. Some notable examples are seen in publications of the Getty Conservation Institute (2011), the Royal Institute of Chartered Surveyors (2011) and the Scientific Symposium of the International Council of Monuments and Sites (ICOMOS) themed Heritage as a Driver of Development (2011). As highlighted in these publications, the notion of the built heritage now gathers cultural values and meanings in a broader context, and the need for heritage is a signal of human societies trying to find themselves in a world dislocating under the effects of globalization. Heritage can move from a passive and aesthetic component, to a more active and assertive one, proposing visions and strategies for future development that combine conservation and 'modernity'. It can provide lessons in reaching a more balanced, sustainable form of development offering cohesive social relationships, human scales and successful adaptation to the physical environment, such as by vernacular buildings that use local materials and techniques. Long considered a factor of additional cost, heritage is increasingly considered as a resource supporting economic development and social welfare. Investment in heritage produces attractive returns and positive impacts on land value, though methods to evaluate this are often still commercial and short-termoriented. Cultural tourism can be a form of sustainable development, as it is integrated within the local socio-economic context and cultural identity. Concepts and methods for the management of historic cities can make essential contributions to urban planning, as the analytical appreciation of the historic city reveals a repository of ideas that can provide continuity in city building. All these opportunities require a change of attitude, where we must question our expectations of buildings, and accept to modify our usage according to local environmental constraints (ICOMOS, 2011, 9-11; Siravo, 2011, 4-5).

A focused look at the economic benefits of heritage conservation is deserved, in light of its impact on shaping the role of urban heritage. Preservationists are increasingly joined by other industries' professionals in defending the economic case for regenerating historic buildings. Important historic buildings that may have been perceived as redundant for contemporary needs are often transformed, through adaptive reuse schemes, to a host of surprising uses that become successful due to their unique character (Allies and Morrison and M\&N, 2011). The inclusion of heritage assets in regeneration schemes provides a focus and catalyst for 
sustainable change. The impact of successful schemes is felt beyond the boundaries of the heritage asset itself and can boost the economy of the whole town. Historic buildings give a sense of place and a focal point that the community will rally around to support. The fabric and design can add a distinctive identity to the new build part of a regeneration scheme, lifting the overall quality of the built environment. They may have interesting historical or cultural associations that can be developed through the wider regeneration area, and attract occupiers who would not be interested in a less distinctive building (Drivers Jonas, 2011, 2-3). Economic benefits are further listed as increased and stabilized property values, which translate into increased property tax revenues; cultural tourism, which translates into increased jobs and increased sales tax revenues; and the building of strong communities and distinctive places where populations wish to live and work. Just the act of restoring one building can encourage others to do the same and improve the value of the entire block. Successful preservation programs foster community pride, learning, and creativity, which are critical to an educated workforce, as a strong economy and a strong community are inextricably linked (Daily Breeze, 2012).

The identification of heritage as catalyzing economic development is only just beginning to be supported by robust and credible analyses, through hard economic measurements, qualitative or environmental indicators (Rypkema and Cheong, 2011a). These measurements help to address the social, economic and environmental contributions of heritage conservation to sustainable development, such as embodied energy, reduced infrastructure expenditure and reduced carbon footprint, and other energy savings of reusing existing built resources. Heritage conservation may be, in fact, the single development strategy that simultaneously advances all aspects of sustainability (Rypkema and Cheong, 2011b).

The economic and social contributions of heritage to urban development are demonstrated to be possible, but depend on certain conditions being in place. Some schemes fail to deliver expected results, due to factors such as unforeseen costs, a beneficial use not being found for buildings, or visitor attractions failing to attract sufficient public interest. Working with heritage assets brings to the development process a special set of conservation, planning, funding and construction considerations, which often require specialist knowledge (Drivers Jonas, 2011, 2-3). The special requirements are further elaborated in a study to assess the outcomes of the Townscape Heritage Initiative set up by the UK Heritage Lottery Fund, which identifies the importance of local knowledge, local capacity, appropriateness of scale, a permanent and stable local population, the presence of community groups, some local money existing in place, appropriate levels of housing market and demand, and a reasonable difference between the rehabilitation costs and the resulting property values of buildings (Shipley and Reeve, 2011). From a broader perspective, the sustainability of urban heritage preservation is contingent on its being part of a larger rehabilitation process that also addresses the issue of turning heritage areas into fully functional and integrated portions of the city (Rojas, 2011, 11-2).

While it is critical to strengthen the quantifiable aspect of the economic role of heritage, this does not mean that qualitative evaluations are no longer as relevant or valid. On the contrary, these two aspects are mutually reinforcing, and integral to a full understanding of development. The term development is defined in the UNESCO Universal Declaration on Cultural Diversity (2001), not simply in terms of economic growth, but 
also as a means to achieve a more satisfactory intellectual, emotional, moral and spiritual existence (ICOMOS, 2011, 9). As the concept gains new dimensions, the types of values at stake become more diverse, and more stakeholders become involved in the debate.

\section{Stakeholder Attitudes and Values}

As our societies are becoming increasingly globalized due to advances in communication and mobility, global market economies fostering new trade and consumption patterns, and the spread of participatory democracies, so the policies of government intervention in planning and preservation are undergoing paradigm shifts. There is a new emphasis on values-based conservation, where the assessment of significance for heritage is made on a premise of the subjectivity of values, and the authority of expertise is questioned or tempered with a diversity of social narratives. This has the potential for a more holistic approach to conservation, integrating independent professional spheres with each other and with society at large, and broadening the audience for heritage. As such, cultural heritage acts as a medium of evolving social values, and its conservation can help manage rapid social changes and mitigate their negative effects (Avrami et al, 2000, 3-4). Conservation is thus required to engage more actively in cultural politics, to assess social and economic, or use and non-use values together, and to quantify the qualitative aspects of cultural capital (Throsby, 2002, 103).

Upon examining the various types of values and their championing stakeholders, ones sees a basic pattern of duality manifested in different forms, e.g. scientific expertise versus social inclusivity, public benefit versus private rights, state intervention versus market forces, or indeed, conservation versus development (or in some instances re-development or regeneration). Socio-cultural values mobilize the cultural elite, philanthropists and community leaders, while economic values attract consumers and real estate investors. A pattern commonly mentioned is the shifting of values, e.g. how heritage has often been perceived as a barrier to regeneration too complicated to work with, or a symbol of decline and social deprivation, but how it is finally being recognized for its true range of cultural, social and economic values. For sustainable preservation programs, one needs to put all values embedded in urban heritage into play, as they are the drivers that mobilize a diverse set of stakeholders; the wider the variety of values, the better heritage can draw the support, financing and skills of diverse and capable stakeholders (Drivers Jonas, 2011, 2-3; Rojas, 2011, 11).

The reconciliation of this duality remains at the center of the debate regarding the role of values-based conservation and governance. It is argued that the question of how this reconciliation is translated into decision-making depends on the level of stakeholder participation, consultation and influence on local and central governments, as well as the driving forces behind the attitudes of decision-making authorities. Making heritage more accessible on a wider social level will enable its acceptance as a valid option for the general public, politicians, decision-makers, contractors, developers and others. For this, effort is needed on both sides, by bringing a more urbanistic approach to the heritage conservation agenda, while improving the position of heritage values within the planning agenda. These can then be transformed from competing alternatives to mutually beneficial components of the same joint agenda. Highlighting the social relevance of this proposition, Siravo $(2011,9)$ points 
out that conservation represents a minority position, but it is all the more relevant in times of environmental concern, and as it offers to overcome the divide between a powerful minority whose members are partisans of unrestrained destructive growth and a powerless minority championing total conservation, and to show how development can be channeled in the interest of a vast majority of users.

At this point, the afore-mentioned reconciliations and negotiations can be applied to the question of whether or not the active role mentioned earlier by Rojas, which the urban cultural heritage should play in the life of the city, can be an economically productive one. A simplistic assumption might place the answer given by the extreme proponents of the development sector as "yes", while that given by conservative members of the heritage conservation sector as "no". However, a more consensual solution can be facilitated as more diverse types of value (i.e. inherent, non-use values as opposed to use values measured strictly in terms of monetary profits manifested in property sales and lease income) are adopted by members of industries such as real estate, economics and engineering, who are classically trained to undertake cost-benefit analyses within purely financial parameters. The definition of productivity can in turn be expanded to allow for new ways of measurement beyond the financial and quantitative, to take into account indirect social benefits and spillover effects into a wider range of urban economic sectors, which contribute to an enhanced quality of life.

Further to the themes mentioned above, some more specific factors related to stakeholders can be acknowledged as influencing the role of heritage within urban development. The critical social and economic characteristics of stakeholders include the demographic profiles and the income levels of the communities residing in historic areas, the level of conservation culture that is internalized by these communities, the strength of the connection between users and the buildings they use, the approach of the local government toward heritage and the skills at managing funds for its conservation. The maturity of public institutions and legislation determines the extent that economic incentives and aid can be offered to owners and users, conservation works on buildings can be facilitated, local governments are empowered to support owners and users, and regulating mechanisms are effective.

Local governments are the best-placed actors capable of ensuring coordination of other stakeholders, through a combination of legal enforcement powers, economic tools and social engagement and outreach abilities. They are increasingly required by communities to take responsibility for preserving the public-good component and the socio-cultural values of urban heritage (Rojas, 2011, 12). Economic tools made available to property owners and users to realize the economic potential of heritage assets, become more potent when local governments can channel the use of funds in a way that maximizes the multiplier effect of incentives, e.g. by providing seed money for privately owned buildings conditional to match funding. Another key tool at the hands of local governments is participatory governance, which has the potential to impact on historic environments through the devolution of land use planning and development control. While this presents an opportunity to mediate between the competing interests of conservation and development, tensions also arise between localized decision-making, and national policy and international obligations to protect heritage (Landorf, 2011). 
To competently handle these sensitive dynamics, it is important to have good technical staff with heritage expertise in local authorities, consisting of well-trained professionals of architecture and planning-related fields, as well as financial and real estate advisers (Getty Conservation Institute, 2011, 19-22).

Beside individual characteristics of stakeholders, the methods of organization between them present another essential factor. In the multi-actor settings of governance of today, successful urban heritage conservation necessitates an effective collaboration between all stakeholders that share responsibility, the ability of key actors to find enlightened partners with whom they can work together, and the presence of a stakeholder that assumes ownership of urban conservation projects and fosters the spirit and culture of collaboration. Similar tenets have been outlined in the literature of site management for historic places. The principles adopted by UNESCO for managing World Heritage Sites, as explained by Feilden and Jokilehto (1993), include the conservation of all values present on the site, consultation with all stakeholders, regular monitoring and reporting done by appropriate experts, and periodic work programs and priorities defined within the strategic conservation plan framework.

While taking note of all the above-mentioned trends in the international conservation discourse, one should cautiously keep in mind that they may not be embraced in the local agendas of all countries. In the following chapters, an examination of some developments in Turkey and the United Arab Emirates will demonstrate that they do not necessarily follow these patterns of stakeholder attitudes in an identical or uniform way, but carve their own paths within this general process.

\section{THE TURKISH CONTEXT}

\section{General Turkish context}

Turkey is home to a rich stock of built heritage, which endows almost every town with historic quarters to be protected. Legal and administrative systems to address the conservation of this legacy have been in development since the 19th century, and have generally followed worldwide trends in the field. However, the size of the population and the socio-economic and geographical dynamics of the country have rendered conservation a constant challenge. Influx of rural migrants into urban areas to form the new industrial workforce, in particular, have made populist policies in local governments prevail at the expense of adequate protection of the urban heritage.

Traditionally, the conservation mandate has been burdened on the government and not fully integrated into the economic life of cities. In the face of the threats posed by these trends, conservation efforts have been undertaken with legislation that was strict, but weakly enforced and illequipped with implementation tools, and a centralized administrative structure, comprising the Cultural Ministry and its provincial branches, which had only meager state resources at hand. These factors confined conservation to the level of a bureaucratic and academic exercise that was marginalized from political decision-making processes, and not taken root as a community-wide culture, in other words not institutionalized in terms of agency and meaning systems. (Şahin and Kurul, 2009, 39). This "top-down" approach, typical of the state-interventionist regime prevalent 
until the 1990s, appeared in the mid-2000s to be giving way to new trends brought about by the evolving democracy of Turkey (Y1ldirım, 2009).

Reflecting the wider trends discussed in the previous section, important new developments related to the accession for European Union membership and EU-compliance reform occurred during the early-to-mid2000s in Turkish cultural heritage legislation. They notably concerned the devolution of government power, whereby increased roles, responsibilities and funding resources were given to local authorities, as well as incentives to private persons and bodies for cultural and natural heritage protection. Beginning in 2003, more than ten new laws and associated regulations were adopted, which had direct and indirect implications for heritage conservation (Table 1). These include:

- new funding sources and responsibilities given to special provincial directorates and municipalities;

- the establishment of municipal Conservation Implementation and Regulation Bureaus (KUDEB) and provincial project and training bureaus;

- the streamlining of bureaucratic procedures;

- new tools for compensation of historic property owners, such as transfer of development rights; and

- an expanded scope for urban regeneration and tourism-related investments.

These changes, while deemed a remarkable legislative and administrative reform, were received with some skepticism in terms of their effectiveness and consequences. Some risks perceived include the new legal powers being abused in favor of large private capital and at the expense of social inclusion and the public interest (Şahin Güçhan and Kurul, 2005, 167), and insufficient institutional capacity to implement the legislation, as well as the lack of a code of ethics to ensure responsible use of legal powers (Madran, 2005, 252).

\begin{tabular}{|l|l|}
\hline $\begin{array}{l}\text { Official Gazette } \\
\text { No. and } \\
\text { Publication Date }\end{array}$ & $\begin{array}{l}\text { Name of Legislation (with decision no. and date and } \\
\text { notes on content) }\end{array}$ \\
\hline 25093/29.04.2003 & $\begin{array}{l}\text { Law no. 4848 on the Establishmentand Duties of the } \\
\text { Ministry of Culture and Tourism (Kültür ve Turizm Bakanlığı } \\
\text { Teşkilat ve Görevleri hk. Kanun) (16.04.2003) }\end{array}$ \\
\hline $25186 / 01.08 .2003$ & $\begin{array}{l}\text { Law no. 4957 on Amendments to the Law on Tourism } \\
\text { Incentives (Turizmi Teşvik Kanununda Değişiklik Yapılması hk. } \\
\text { Kanun) (24.07.2003) }\end{array}$ \\
\hline $25334 / 02.01 .2004$ & $\begin{array}{l}\text { Law no. 5035 on Amendments to Some Laws (Bazı } \\
\text { Kanunlarda Değişiklik Yapılması hk. Kanun) (25.12.2003) } \\
\text { (articles 14 and 16: deduction from taxed income of } \\
\text { expenses related to cultural property) }\end{array}$ \\
\hline $25475 / 04.03 .2005$ & $\begin{array}{l}\text { Law no. 5197 on Special Provincial Administrations (İl Özel } \\
\text { İdaresi Kanunu) (24.06.2004) }\end{array}$ \\
\hline $25531 / 23.07 .2004$ & $\begin{array}{l}\text { Law no. 5216 on Metropolitan Municipalities (Büyükş̧ehir } \\
\text { Belediyesi Kanunu) (10.07.2004) }\end{array}$ \\
\hline
\end{tabular}




\begin{tabular}{|c|c|}
\hline $25531 / 23.07 .2004$ & $\begin{array}{l}\text { Law no. } 5217 \text { on Amendments to Some Laws and Decrees } \\
\text { on the Arrangement of Special Incomes and Funds (Özel } \\
\text { Gelir ve Özel Ödeneklerin Düzenlenmesi ile Bazı Kanun ve } \\
\text { KHKlerde Değişiklik Yapılması hk. Kanun) (14.07.2004) } \\
\text { (articles } 8 \text { and 17: funds in the budget of the Ministry of } \\
\text { Culture and Tourism) }\end{array}$ \\
\hline $25529 / 21.07 .2004$ & $\begin{array}{l}\text { Law no. } 5225 \text { on the Encouragement of Cultural } \\
\text { Investments and Initiatives (Kültür Yatırımlarını ve } \\
\text { Girişimlerini Teşvik Kanunu) (14.07.2004) }\end{array}$ \\
\hline $25535 / 27.07 .2004$ & $\begin{array}{l}\text { Law no. } 5226 \text { on Amendments to the Law on the } \\
\text { Conservation of Cultural and Natural Property (Kültür } \\
\text { ve Tabiat Varlıklarını Koruma Kanun ile Çeşitli Kanunlarda } \\
\text { Değişiklik Yapılması hk. Kanun) (14.07.2004) }\end{array}$ \\
\hline $25539 / 31.07 .2004$ & $\begin{array}{l}\text { Law no. } 5228 \text { on Amendments to Some Laws and Decree } \\
\text { no. } 178 \text { (Bazı Kanunlarda ve } 178 \text { sayılı KHKde Değişiklik } \\
\text { Yapılması hk. Kanun) (16.07.2004) (tax reductions) }\end{array}$ \\
\hline $25866 / 05.07 .2005$ & $\begin{array}{l}\text { Law no. } 5366 \text { on Conservation by Renovation and Use by } \\
\text { Revitalization of the Deteriorated Historical and Cultural } \\
\text { Immovable Property (Yıranan Tarihi ve Kültürel Taşınmaz } \\
\text { Varlıkların Yenilenerek Korunması ve Yaşatılarak Kullanılması } \\
\text { hk. Kanun) (16.06.2005) (1) }\end{array}$ \\
\hline $25874 / 13.07 .2005$ & $\begin{array}{l}\text { Law no. } 5393 \text { on Municipalities (Belediye Kanunu) } \\
(03.07 .2005)\end{array}$ \\
\hline $25698 / 12.01 .2005$ & $\begin{array}{l}\text { Regulation on the Work of the Superior Council for the } \\
\text { Conservation of Cultural and Natural Property and } \\
\text { Regional Conservation Councils and Objections Brought } \\
\text { Before the Superior Council of Conservation (Kültür ve } \\
\text { Tabiat Varlıklarını Koruma Yüksek Kurulu ve Koruma Bölge } \\
\text { Kurulları Çalışmaları ile Koruma Yüksek Kuruluna Yapılacak } \\
\text { Itirazlara dair Yönetmelik) }\end{array}$ \\
\hline $25785 / 13.04 .2005$ & $\begin{array}{l}\text { Regulation on the Contribution Fee for the Conservation of } \\
\text { Immovable Cultural Property (Taşınmaz Kültür Varlıklarının } \\
\text { Korunmasına ait Katkı Payına dair Yönetmelik) }\end{array}$ \\
\hline $\begin{array}{l}\text { 25842/ 11.06.2005 } \\
\text { (amendment: } \\
\text { 29198/ 07.12.2014) }\end{array}$ & $\begin{array}{l}\text { Regulation on the Principles of Building and Control of } \\
\text { Immovable Cultural Property to Be Protected (Korunması } \\
\text { Gerekli Taşınmaz Kültür Varlıklarının Yapı Esasları ve } \\
\text { Denetimine dair Yönetmelik) }\end{array}$ \\
\hline $25842 / 11.06 .2005$ & $\begin{array}{l}\text { Regulation on the Procedures of the Establishment and } \\
\text { Duties of Conservation Implementation and Regulation } \\
\text { Bureaus, Project Bureaus and Training Units (Koruma, } \\
\text { Uygulama ve Denetim Büroları, Proje Büroları ile Eğitim } \\
\text { Birimlerinin Kuruluş, İzin, Çalışma Usul ve Esaslarına dair } \\
\text { Yönetmelik) ('KUDEB's) }\end{array}$ \\
\hline $\begin{array}{l}\text { 25849/ 18.06.2005 } \\
\text { (amendment: } \\
\text { 27315/ 10.08.2009) }\end{array}$ & $\begin{array}{l}\text { Regulation on the Procurement of Goods and Services } \\
\text { for the Surveys, Restoration, Restitution Projects, Street } \\
\text { Rehabilitation and Landscaping Projects for the Cultural } \\
\text { Assets Covered by the Law on Conservation of Cultural } \\
\text { Natural Property as well as for Implementation and } \\
\text { Assessment Thereof Including Storage, Transport Works } \\
\text { and Excavation Works Associated Therewith (Kültür ve } \\
\text { Tabiat Varlıklarııı Koruma Kanunu Kapsamındaki Kültür } \\
\text { Varlıklarının Rölöve, Restitüsyon, Restorasyon Projeleri, } \\
\text { Sokak Sağlıklaştırma, Çevre Düzenleme Projeleri ve Bunların } \\
\text { Uygulamaları ile Değerlendirme, Muhafaza, Nakil İşleri ve Kazı } \\
\text { Çalışmalarına ilişkin Mal ve Hizmet Alımlarına dair Yönetmelik) } \\
\text { (tender procedures) }\end{array}$ \\
\hline $25876 / 15.07 .2005$ & $\begin{array}{l}\text { Regulation on Aid for the Repair of Immovable Cultural } \\
\text { Property (Taşınmaz Kültür Varlıklarının Onarımına Yardım } \\
\text { Sağlanmasına dair Yönetmelik) }\end{array}$ \\
\hline
\end{tabular}

1. Although part of this 'reform package', this law has been debated extensively due to its problematic implications related to 'renewal'. 
Table 1. List of laws and associated regulations issued between 2003-2005 forming the reform package.

\begin{tabular}{|l|l|}
\hline 26006/ 27.11.2005 & $\begin{array}{l}\text { Regulation on the Procedures and Principles regarding } \\
\text { Site Management, the Establishment of Monument } \\
\text { Councils and the Identification of Management Areas (Alan } \\
\text { Yönetimi ile Anıt Eser Kurulunun Alan Alan Yönetimi ile Anıt } \\
\text { Eser Kurulunun Kuruluş ve Görevleri ile Yönetim Alanı'nın } \\
\text { Belirlenmesine Illişkin Usul ve Esaslar Hakkında Yönetmelik) }\end{array}$ \\
\hline $26023 / 14.12 .2005$ & $\begin{array}{l}\text { Regulation on the Implementation of the Law on } \\
\text { Conservation by Renovation and Use by Revitalization } \\
\text { of the Deteriorated Historical and Cultural Immovable } \\
\text { Property (Yıranan Tarihi ve Kültürel Taşınmaz Varlıkların } \\
\text { Yenilenerek Korunması ve Yaşatılarak Kullanılması hk. Kanunun } \\
\text { Uygulama Yönetmeliği) }\end{array}$ \\
\hline
\end{tabular}

This legislative reform coincides with certain socio-economic trends that have been occurring in Turkey since the 1990s. Among promising trends are:

- an increased general interest in and improved public perception of heritage preservation, fed by media coverage and the new awareness of economic value to be gained through cultural tourism, especially by local governments,

- many municipal leaders becoming motivated toward conservation through organizations like the Union of Historic Towns and nongovernmental organizations such as citizen groups and professional chambers,

- a shift away from centralized, modernist spatial planning toward strategic planning and the emergence of site management plans, particularly in the context of World Heritage Sites,

- the adoption of the new concepts of sustainability, livability, devolution and governance covered within the UN-based Local Agenda 21,

- increasing international sponsorship through programs of the European Union (e.g. Fener and Balat Rehabilitation project of 2002) and funding bodies such as the World Monuments Fund (e.g. for Ani) and the World Bank (e.g. the Southeast Anatolia Cultural Heritage Project) and

- the increased interest of national private companies (e.g. Koç, İçdaş, İşbank) in cultural investments.

While these trends have presented opportunities supporting heritage conservation, they have been accompanied by controversial project investments by international and national corporate capital in historic sites at prime urban locations, mainly in İstanbul, in line with neoliberal tendencies of the government. As profit and execution speed are favored in these projects over the conservation of the authentic social and physical fabric (Dinler, 2013, 151), as well as fundamental master planning principles (Dinçer, 2011, 10-1), they subsequently draw the reactions of expert and community groups through court battles and protest campaigns (e.g. Haydarpaşa Port, Galataport, Fener and Balat Urban Renewal Project of 2008, and the Sulukule and Tarlabaşı Renewal Projects).

These trends have all helped to increase the number of actors in the preservation sphere, coming together both in terms of their conflicting interests, such as in preservation battles, and in terms of collaborations, 
2. For a full account of the case studies, please see the doctoral dissertation, available in full text at https://tez.yok.gov.tr/ UlusalTezMerkezi

3. 23 out of 40 questionnaire returns were acquired from the secondary case studies of:

a) Large cities: Ankara (Altındağ), İnci ve Dutlu Sokakları Sağlıklaştırma Projesi;

Antalya (Merkez), Tarihi Kültürel Merkez Projesi; Bursa (Osmangazi), Bursa

Kültür Yolu Canlandırma Projesi; Bursa

(Osmangazi), Tuz Hanı Restorasyon

Projesi; İstanbul (Fatih), Fener Balat Kentsel Rehabilitasyon Projesi; İstanbul (Kadıköy), Kadıköy Tarihi Çarşı Canlandırma Projesi; İzmir (Konak), Bakımlı Cepheler Projesi

b) Medium-sized cities: Afyon (Merkez), Ulu Cami Çevresi ve Afyonkarahisar Kalesi Giriş Mekanı Kentsel Tasarım Projesi; Çanakkale (Merkez), Çarşı Caddesi ve Yakın Çevresi Cephe İyileștirme ve Sağlıklaştırma Projesi; Eskişehir (Odunpazarı), Odunpazarı Evleri Yaşatma Projesi; İzmir (Ödemiş), Tarihi Arasta Bölgesi Sokak Sağlıklaştırma Projesi; Kayseri (Talas), Kiçiköy Ali Saib Paşa Sokak Sağlıklaştırma Projesi; Kütahya (Merkez) Büyük Bedesten Restorasyonu ile Saraçhane ve Kavaflar Sokak Cephe İyileştirmesi Projesi; Muğla (Merkez), Muğla Arastası Projesi; Sivas (Merkez), Selçuk Parkı ve Kent Meydanı Projesi; Sanlıurfa (Merkez), Hanlar Bölgesi Sağlıklaştırma Projesi; Tokat (Merkez), Sulu Sokak Kentsel Tasarım Projesi

c) Small cities: Bartın (Merkez), Hükümet Caddesi Revitalizasyon Projesi ('Kültürel Peyzaj'); Isparta (Yalvaç), Doğal ve Kültürel Değerlerin Korunması, Geliştirilmesi ve Turizmin Çeşitlendirilmesi Projesi Birgi (Ödemiş), Sokak ve Meydan Cephe Sağlıklaştırmaları; Birgi (Ödemiş), Şehit Gürol Madan Caddesi Sokak Sağlıklaştırma ve Cephe Restorasyonu Projesi; Nevşehir (Ürgüp), Kayakapı Mahallesi Kültürel ve Doğal Çevre Koruma ve Canlandırma Projesi; Sakarya (Taraklı), Tarihî Ahşap Evlerin Restorasyonu ve Orhangazi ve Yunuspaşa Çarşıları Sokak Sağlıklaştırma Projesi such as international and public- private partnerships. In the era of reform of the mid-2000s, two important implications emerged. Firstly, the relaxation of centralized government control gave way to more varied and contested views of preservation and to less strict applications of preservation principles. Secondly, the view of preservation as an economic revenue generator produced initiatives for projects to preserve and reuse historic fabric on one hand, and potential abuse through misguided interventions on the other. In other words, it was possible to foresee a quantitative rise and qualitative fall in urban conservation projects and practices.

These challenges and opportunities presented processes that needed to be monitored and optimized through some basic measures throughout their implementation. These include staff and technical assistance to the highly underserved local authorities to provide guidance in interventions; the community sector to rise to the challenge of checking speculative interests in the private and government sectors empowered by the new laws; incentivizing good practices among private sector investors; and forming the 'right' type of partnerships in conservation projects that would achieve optimal results. The biggest challenge was suggested to be ensuring that the new institutional framework, with its central and local government bodies, would be fully developed into one that safeguarded heritage (Şahin and Kurul, 2009, 39).

\section{Specific Turkish Cases from the Period 2000-2011}

Empirical research conducted during the author's doctoral dissertation, which explores the governance framework of actors in the urban conservation process, has provided some insights that elaborate on the propositions outlined above (2). The main hypothesis of the dissertation was that "for a successful project, the governance framework must include the active participation of four types of actors, i.e. Statutory Authorities, Investors, Users and Experts, to fulfill the respective requirements of legal, financial, social and scientific credibility of projects, as well as a fifth actor who will be the Project Owner." The focus case studies were the cities of Gaziantep, Kuşadası and Mudurnu, where in-depth desktop and field research (interviews, questionnaires, site visits) were conducted, supplemented by forty secondary case studies studied primarily through questionnaires (3). The selection method was based on a representative typology of scale and urban development pressure/ dynamism, where noteworthy historic urban fabric were found and substantial efforts made in the preceding ten years for their conservation. The Union of Historic Towns publications showcasing the Union's project awards was a major source for the database of candidate case studies.

In the metropolitan municipality of Gaziantep, the Kültür Yolu Project (the Culture Trail Project), which was part of a wider initiative called Varlığını Berekete Dönüştüren Kent (Gaziantep: The City that Turns its Assets into Abundance), features a $5.5 \mathrm{~km}$ axis connecting the citadel with the historical commercial center, where street and building façade rehabilitation, infrastructure and landscape improvements, and restorations and adaptive reuse of historic buildings were carried out, aimed at revitalizing the historic center and integrating it into the social life of the city (Figure 1,2). The project was initiated with the election of a new mayor with such a vision, and successfully implemented though strong municipal leadership and coordination, which revolves around the multiactor Ortak Akıl Platformu (Common Mind Platform) (Figure 3). Here, the 
Figure 1. Illustration of the Gaziantep 'Culture Trail Project' area (Gaziantep Metropolitan Municipality, 2008)

Figure 2. View of the Bakırclar Çarşısı (Coppersmiths' Bazaar), Gaziantep, after restoration (photo: E. Ylldırım, 2009)

Figure 3. Multi-stakeholder site visit for Gaziantep's 'Culture Trail Project' (Gaziantep Metropolitan Municipality, 2008)
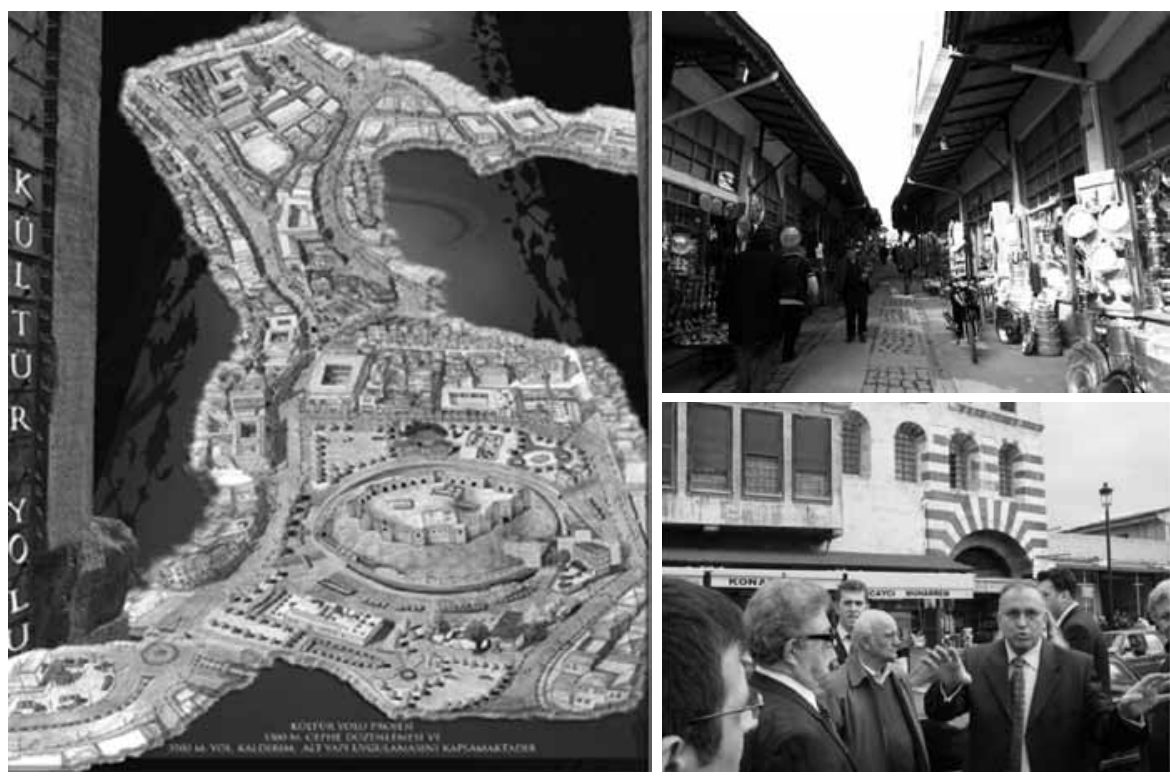

urban cultural heritage is clearly seen as a vital component of the vision for the city; rediscovered after a long period of being overshadowed by the city's image as a center of industry. The diverse and concerted efforts for conservation and refunctioning of many historic buildings not only rendered them economically more productive through increased tourism and local use, but also as an element of prestige and branding in a more general sense.

In the mid-sized tourist resort town of Kuşadası, the Kaleiçi Bölgesi Sokak Sağliklaştırma Projesi (Kaleiçi Quarter Street Rehabilitations Project), which was part of a wider initiative called Kuşadası Doğal ve Kültürel Kimliğini Yeniden Kazanıyor (Kuşadası Reclaims its Natural and Cultural Identity), features street and building façade rehabilitation, infrastructure and landscape improvements. Kuşadası Municipality formed a strong partnership with the Foundation for the Protection and Promotion of the Environment and Cultural Heritage (ÇEKÜL) and various universities' architectural faculties for the project, and mobilized match funding from resident merchants for street improvements. In this case, the urban cultural heritage was addressed in association with the natural assets of the city and environs, and the historic core regained visibility as a small but critical element of cultural tourism, in a move to turn back the imprint of environmental degradation after decades of mass tourism.

In the small Silk Road town of Mudurnu, the Geleneksel Mimarlik Örneklerinin Korunarak Turizm İşleviyle Yaşatılması Projesi (Project for Tourism-based Revitalization of Traditional Architecture) involved efforts to revitalize the economy through cultural tourism, after the collapse of the poultry industry in the economic recession of 2001, through minor and comprehensive repairs in historic buildings, adaptive reuse for tourism, and visual improvements in the public realm (Figure 4,5). The special success of the Municipality, in coordination with the Provincial Directorate for Culture and Tourism, was in mobilizing funds provided by the new grant scheme of the Ministry of Culture and Tourism, for the design and execution of thirty restoration projects (Figure 6). As for this case, the urban heritage, though long recognized as a major character-defining element 
Figure 4. Panoramic view of Mudurnu (photo: E. Yıldırım, 2009)

Figure 5. Delegation from İzzet Baysal University in front of Haytalar Mansion, Mudurnu, which the university planned to take over for restoration and reuse (photo: E. Yıldırım, 2009)

Figure 6. A traditional house of Mudurnu undergoing restoration works with funding from the Ministry of Culture and Tourism (photo: E. Yildırım, 2009)
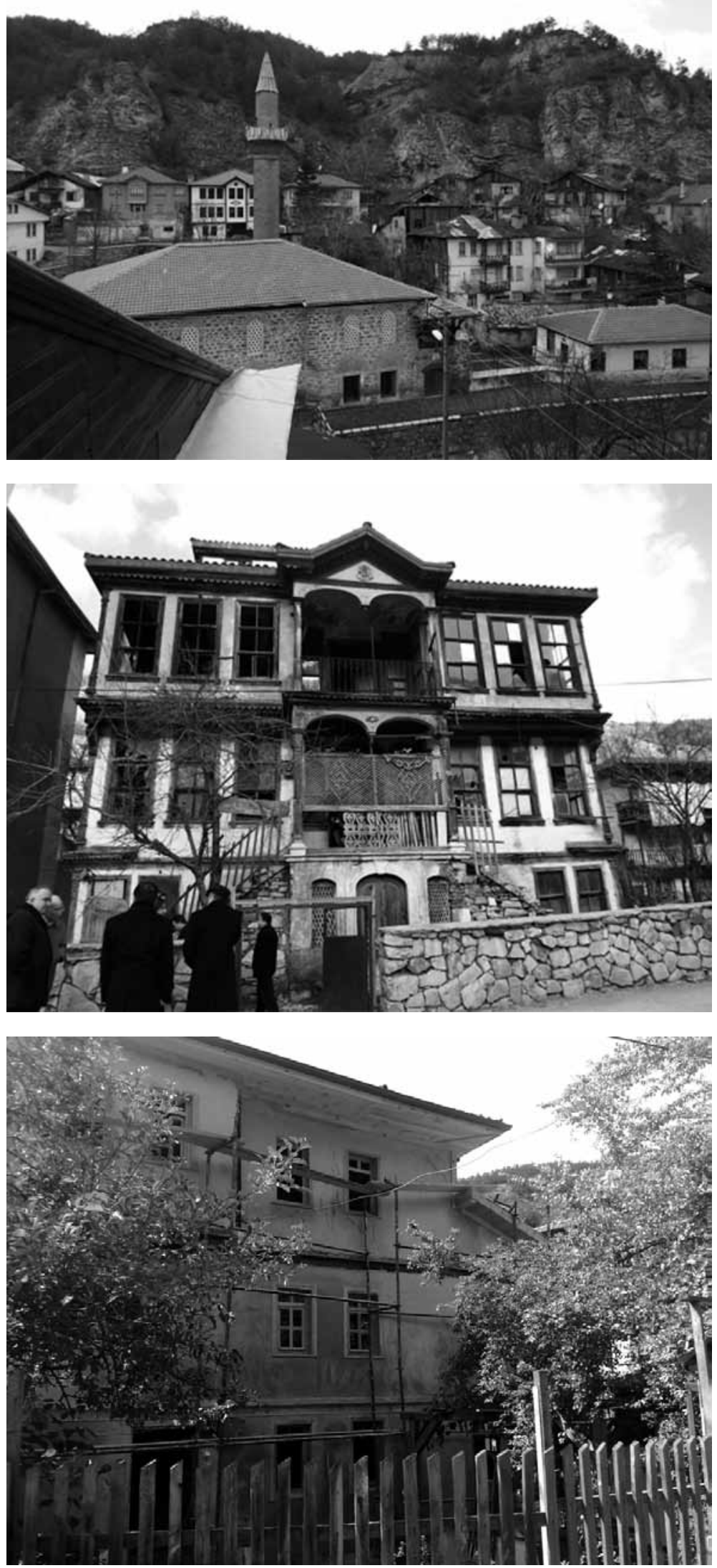
of the town, was given a more active economic role, as a new mission was defined to harness it more directly toward generating tourism income.

The examined projects, including both the three focus and forty secondary case studies, revealed some successful outcomes, such as transformation of the project areas- most of which had less development dynamics compared to the rest of the city- into more attractive destinations through physical improvement and increase in use and economic activity; enhancement of the city's identity; emergence of social and economic expectations from the local government and community toward the urban heritage; setting an example and providing impetus for other projects; actors sharing ownership of project, and development of a local preservation culture. Some points of concern also emerged, mostly related to interventions being superficial and lacking full technical and scientific competence. However, a general attitude of optimism and a resolution to continue works was observed, as well as a tendency of implementation improving in quality, as lessons were drawn from mistakes in earlier project phases.

Some important points observed regarding the project processes were that partnerships are based on ease of implementation (e.g commercial districts being favored in initial phases over residential, as co-funding by local traders is possible), and there was a notable element of public participation, through information and consultation meetings with business owners, and multi-actor committees set up either for the specific project or operating city-wide.

The main stakeholders of urban conservation projects, in order of importance, emerged as Municipalities, with a particularly active role played by individual mayors, Cultural and Natural Heritage Conservation Councils, and Governorships. The role of Project Owner is played mostly by the metropolitan or district municipality, supported by the Ministry of Culture and Tourism and the Directorate of Foundations. A wide range of actors act as project partners, including the Directorate of Surveying and Monuments within the Ministry, the ÇEKÜL Foundation and its local branches, the Union of Historic Towns, the Chamber of Architects, and private architectural practices. Project funding came mainly from Municipalities, grants distributed by the Special Provincial Administrations based on the new real estate tax co-payment scheme, international funding bodies and the Ministry of Culture and Tourism.

The case study findings suggest that positive processes and outcomes are produced when all of the ' $4+1$ ' actor types are involved, thus generally supporting the hypothesis of the dissertation. Perhaps more pertinently, the key issue that needs to be addressed for success appears as maintaining the productive momentum of projects without compromising on scientific standards. From the governance perspective, this entails the balance between the regulating role of the experts and users and the executive role of the investors and statutory authorities (Figure 7). To achieve this, an effective system of coordination between these parties is required, harnessing as many channels of communication and collaboration as possible. Other factors to consider include actors being involved in full capacity, whereby mandatory roles defined by legislation are supported by voluntary roles; technical capacity building for municipal staff through support from experts; project continuity being achieved, on a technical level by involvement of dedicated experts throughout design and implementation, and on an institutional level through long-term, lasting governance structures independent of electoral politics, being put 
Figure 7. Actor typology and proposed governance model featuring ten foremost actors in urban conservation in Turkey

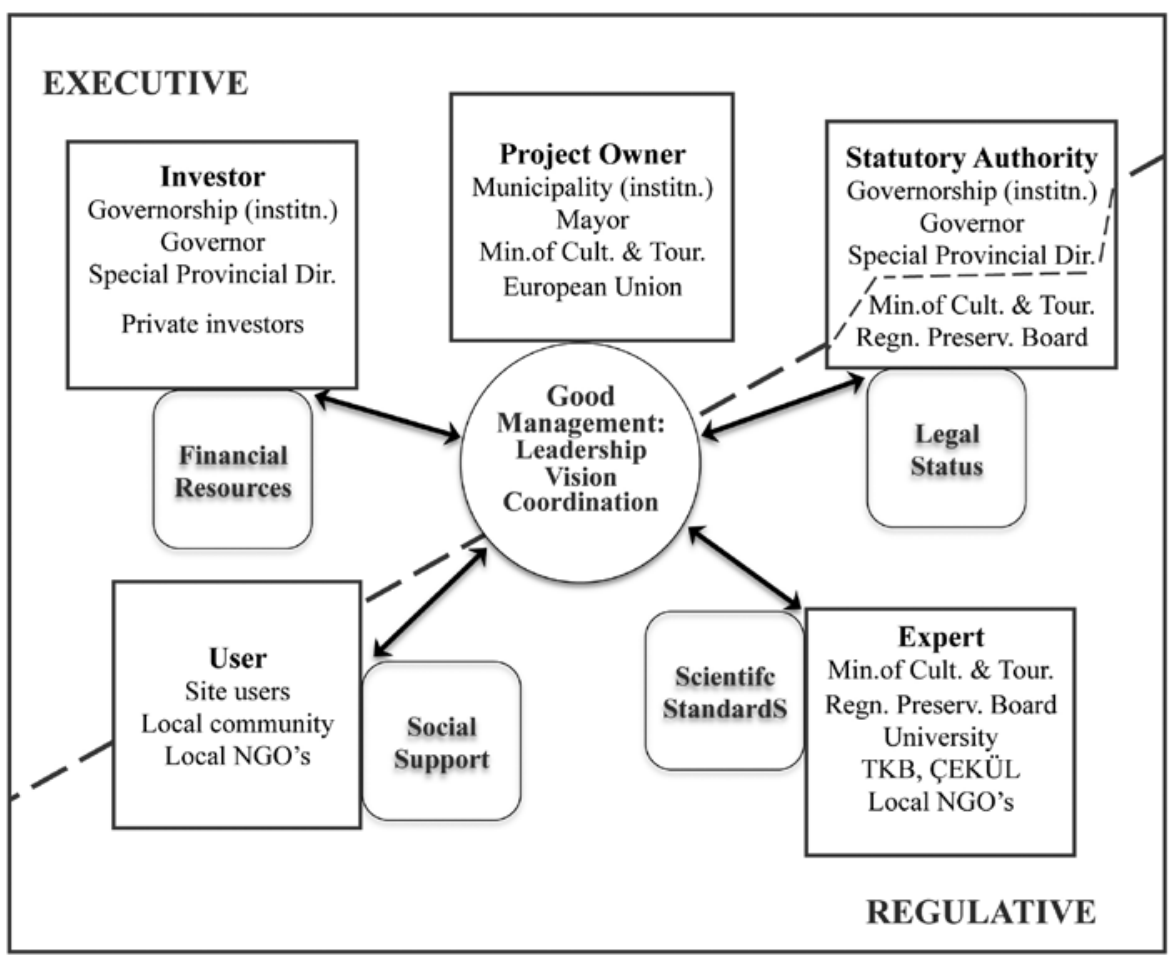

in place. These measures also help reinforce awareness and the culture of preservation in the community.

The empirical research yielded many instances of urban conservation and stakeholder involvement in Turkey, where one could note positive trends toward more social engagement, more opportunities to realize the economic potential, and heritage becoming a more visible component of the city image and of the strategic visions for the cities' futures. For many plans and projects that could not find the funds to be implemented before, the opportunity to implement arrived, and began to be realized with varying degrees of success and competence, but nevertheless with great enthusiasm and a positive trajectory of improvement.

\section{Post-2011 Remarks}

While the research of 2008-11 outlined above contributed to the evidence of positive stakeholder engagement with urban heritage in Turkey, developments that occurred afterwards have taken a more pessimistic turn, leaving the positive case studies in a less significant position. Beside new controversial redevelopment-projects (e.g. Yedikule Gardens in Istanbul, Namik Kemal Neighborhood in Ankara, and last but not least, Gezi Park in İstanbul), several legislative changes in the past three years (Table 2) have undone some of the progressive reforms of the early 2000s mentioned earlier, reversing the general trend of democratization (4).

Decree no. 648 (and associated decrees 644, 645) separate the jurisdiction of cultural and natural assets, which contradicts the current international trends of integrating these within holistic frameworks (e.g. cultural landscape, urban historic landscape). The decree has also restricted the participation rights of professional chambers in conservation council meetings, a step back from rights granted in Law no. 5266. Law no. 6306
4. The latest series of legislative changes appear to be ongoing, as news of yet another package is on the agenda, with further implications along the same line as the other post-2011 laws mentioned. 
Table 2. List of laws and decrees issued in 2011-12, reversing the democratic reform package.

\begin{tabular}{|c|c|}
\hline No./ Date & Name of Law/ Decree (with notes on content) \\
\hline 27984/ 04.07.2011 & $\begin{array}{l}\text { Decree no. } 644 \text { on the Establishment and Duties of the } \\
\text { Ministry of Environment and Urbanization (Çevre ve } \\
\text { Şehircilik Bakanlığının Teşkilat ve Görevleri Hakkında Kanun } \\
\text { Hükmünde Kararname) (29.06.2011) }\end{array}$ \\
\hline 27984/ 04.07.2011 & $\begin{array}{l}\text { Decree no. } 645 \text { on the Establishment and Duties of the } \\
\text { Ministry of Forestry and Waterworks (Orman ve Su İşleri } \\
\text { Bakanlığının Teşkilat ve Görevleri Hakkında Kanun Hükmünde } \\
\text { Kararname) (2011) }\end{array}$ \\
\hline $28028 / 17.08 .2011$ & $\begin{array}{l}\text { Decree no. } 648 \text { on Amendments to the Decree on the } \\
\text { Establishment and Duties of the Ministry of Environment } \\
\text { and Urbanization and to Some Laws and Decrees (Çevre ve } \\
\text { Şehircilik Bakanlığının Teşkilat ve Görevleri Hakkında Kanun } \\
\text { Hükmünde Kararname ile Bazı Kanun ve Kanun Hükmünde } \\
\text { Kararnamelerde Değişiklik Yapılmasına dair Kanun Hükmünde } \\
\text { Kararname) (08.08.2011) }\end{array}$ \\
\hline $28309 / 31.05 .2012$ & $\begin{array}{l}\text { Law no. } 6306 \text { on Regeneration of Areas under Disaster Risk } \\
\text { (Afet Riski Altındaki Alanların Dönüştürülmesi hk. Kanun) } \\
(16.05 .2012)\end{array}$ \\
\hline $28489 / 06.12 .2012$ & $\begin{array}{l}\text { Law no. } 6360 \text { on the Establishment of Metropolitan } \\
\text { Municipalities in Thirteen Provinces and the Establishment } \\
\text { of Twenty-Six Districts and Amendments to Some Laws } \\
\text { and Decrees (On Üç İlde Büyükşehir Belediyesi ve Yirmi } \\
\text { Altı İlçe Kurulması ile Bazı Kanun ve Kanun Hükmünde } \\
\text { Kararnamelerde Değişiklik Yapılmasına dair Kanun) } \\
\text { (12.11.2012) }\end{array}$ \\
\hline
\end{tabular}

has enabled decisions for renewal projects and emergency expropriations to be taken for areas deemed at risk of natural hazards, at risk of collapse and which have completed their economic life; the fact that criteria for selection are left arbitrary and the conservation legislation is superseded by this law are serious causes for alarm (Madran, 2013, 13). Finally, Law no. 6360 has brought a general consolidation of power at the provincial level (noticeably coinciding with the time leading up to elections), destroying the integrity and self-sufficiency of villages and townships, thus cutting back democratic representation at the local level. (Keleş, 2014, 29-33; Deveci, 2013).

These legislative changes can be linked most readily to a new shift in attitudes of the central government, which was already the most powerful stakeholder in Turkish governance, but reached a new kind of unbalanced power in its third term of office, which began around the same time (5). The misinterpetation and manipulation by decision-makers of the conservation legislation indicate that the risks foreseen ealier, i.e. that the economically productive role of the urban heritage would overshadow other interests like the public good, social inclusion, and the authenticity of historic areas, is proving to become a reality in many cases. These actions appear as symptoms of neoliberal economic policies that have become prevalent in Turkey in the last decades, beside the other developments mentioned earlier, which have put pressures on both protected urban and natural sites and urban areas in general. In this environment of weakened checks and balances, it is all the more important for other actors to assert their positions defending the conservation of heritage, so that the next wave of developments may perhaps bring more equitable and sustainable practices.
5. This power looks set to start diminishing after the June 2015 general elections, where the ruling party has lost its absolute majority in parliament; this development occurred just as this article was about to be published. 


\section{THE EMIRATI CONTEXT}

\section{Overview of the general Emirati context}

The heritage of the United Arab Emirates has been marked by the astoundingly rapid transformation of the country through its oil wealth, from a confederation of semi-nomadic tribes surviving on a basic subsistence economy into a futuristic post-modern landscape. The distinction of the post-Oil UAE from the pre-Oil period is clearly reflected in the country's social and physical characteristics, but a continuum of layers of urban growth can still be traced in this transition. Beside the survival of a short but vital urban layer attesting to the history of modernization, Emirati cultural heritage can be gleaned through traditions linked with a strong adherence to Islamic practices, enduring references to a nomadic, desert-bound lifestyle, and intangible heritage elements such as poetry, camel-herding and falconry. There are also important archaeological remains and ancient oases dating back to the Bronze and Iron Ages, which together form a cultural landscape that has evolved and survived to the present day. The rapid development of the 20th century has caused major loss of the pre-Oil urban fabric, leaving behind mostly monumental structures such as Qasr al Hosn in Abu Dhabi, and some traces of villages that can be found at the edges of oases in Al Ain. Although the traditional built heritage is not substantial, the intangible and rural elements find their references in the modern urban landscape, producing an unusual mixture of urban heritage. The country owes its modern-day achievements to the masses of expatriate workers and professionals taking up residence there, forming a highly multi-cultural population that has indirectly contributed to the urban culture (Yildirım and El Masri, 2010, 1).

The UAE is essentially a monarchy, but has some distinctive features that suggest a more democratic governance structure than one might presume. Firstly, the country is a federation of seven separate emirates, each with a certain amount of autonomy that includes a local mandate for culture; secondly, the tribal governance structure centered around the majlis tradition of consultation enables a considerable degree of upward feedback of the communities' interests to the rulers to consider. With the advent of civic institutions, the government has adopted modern state organs such as the Federal National Council, but these have been superimposed on, coexisting with, and thus affected by local tribal structures. The urban development projects, which began with the flow of funds from oil exports in the 1960s, were initially directed from the Rulers' courts, but soon the realization of development plans required the establishment of government departments for specialized operations, which eventually led to the creation of federal ministries after unification as a nation-state in 1971. Today, local governments have a very high profile in the development of the physical world, as development budgets and projects are allocated by the Executive Councils representing the government of each emirate (Damluji, 2006, 16, 36).

This article focuses on the heritage of Abu Dhabi, the largest and wealthiest of the seven emirates, the namesake capital city of which is also the seat of the federal state. In terms of the study and conservation of heritage, the development of stakeholders and activities in Abu Dhabi can be traced back to archaeological excavations in the mid-20th century, which started under the auspices of the late president Sheikh Zayed, and the establishment of the Center of Documentation and Research to record the 
emirate's history and resolve territorial issues. This was followed by the Department of Antiquities and the Al Ain Economic Development and Tourism Promotion Authority, which asked for UNESCO's support in preparing the Abu Dhabi Cultural Heritage Management Strategy. Completed in 2005, the Strategy promoted an integrated approach to the management of the emirate's cultural heritage, and recommended the establishment of the Abu Dhabi Authority for Culture and Heritage (ADACH) to implement this vision. The founding Law no. 28 of 2005 charged ADACH with a broad mandate for this end, and placed it among several new Abu Dhabi government agencies that have been expected to guide Abu Dhabi's ambitious future development (Yildırım and El Masri, 2010, 1-2). These agencies include the Abu Dhabi Urban Planning Council (UPC), the Department of Municipal Affairs overseeing Abu Dhabi, Al Ain and Western Region Municipalities, the Department of Transport (DoT) and the Environment Agency (EAD). In 2012, ADACH was integrated with the Abu Dhabi Tourism Authority (ADTA) to form the Abu Dhabi Tourism \& Culture Authority (TCA) (Khaleej Times, 2012). This restructuring is viewed by some as an indicator of a shift in the emirate government's policy toward engaging culture and heritage more actively in economic development.

The Abu Dhabi government showed strong initiative also in adopting the Abu Dhabi 2030 Policy Agenda, in development since the mid-2000s. Cultural heritage is given an important role at policy level, as one of the main subject areas in the agenda; however, the level of implementation has revealed challenges, as it is often not clear how conflicts arising between the mandates of different agencies will be resolved and how the government's priorities will be negotiated. The policy agenda has been followed by sectoral versions, foremost among them the Abu Dhabi Economic Vision 2030, as well as the Environment 2030 agenda. It has not been clearly defined how cultural heritage features within this agenda, i.e. in terms of the social, environmental and economic 'pillars' of sustainability, but this may be a point that will be addressed among the agencies in future deliberations, as the $\mathrm{EAD}$ and former $\mathrm{ADACH}$ have many procedural and practical relations in effect.

The emirate government's predominant role also manifests itself as the primary funding source for both development and heritage conservation projects; the government's decision to cut back the budgets of many agencies, which was interpreted as a strategic move in the wake of the 2008 economic recession, affected the heritage conservation work at TCA.

On a level below the emirate, municipalities have exercised their regulatory capacity in a way that has shaped the formation of new urban layers. During the 1980s, by-laws of the Department of Town Planning have required new buildings, particularly residential ones, to feature architectural elements of the Arab/ Islamic style on their elevations. Intended to reflect regionalism, the effect of this has been criticized by scholars to produce only superficial decorative features, often without consideration for the underlying principles of Islamic architecture (Damluji, 2006, 32).

Similarly, the misappropriation and literal application of features of traditional architecture such as wind towers and desert forts have produced unintended consequences, misrepresenting the identity of the built heritage (Allies and Morrison and M\&N, 2011). Here, the quality and role of design professionals becomes key as they interpret and reproduce 

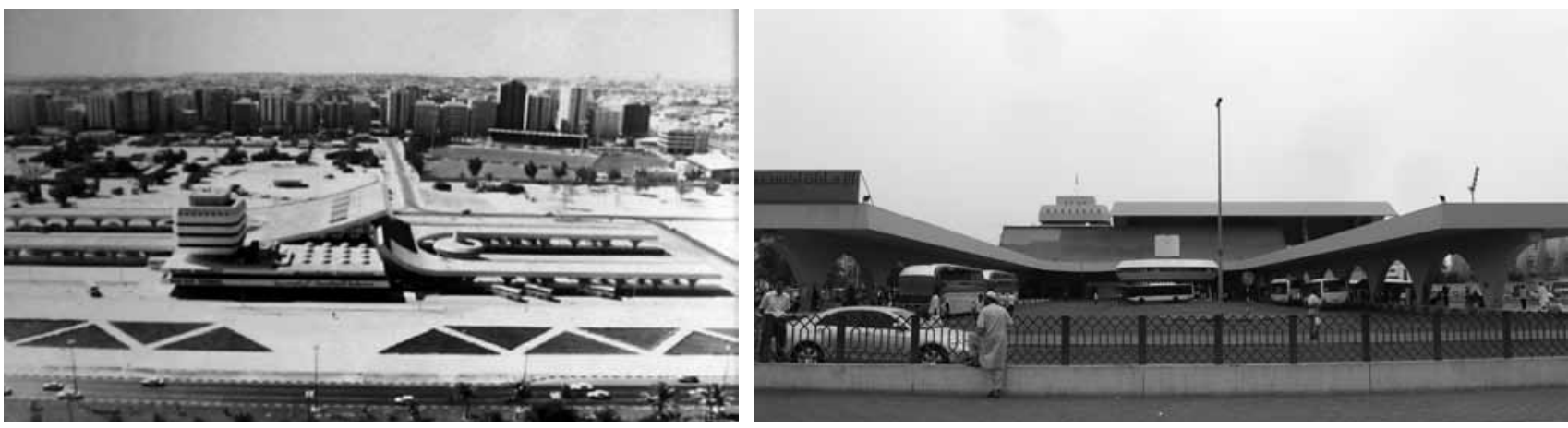

Figure 8. Abu Dhabi Bus Station, c. 1970 (Abu Dhabi Tourism \& Culture Authority archive)

Figure 9. Abu Dhabi Bus Station, c. 2011 (Abu Dhabi Tourism \& Culture Authority archive) the regional cultural identity. Damluji $(2006,36)$ provides some insights into this, such as the conventional architectural education in the region having been oriented towards structural engineering, and the influx into the region of architects from different backgrounds and senses of aesthetics during the post-Oil decades resulting in the experimental nature of the architectural profession (Damluji, 2006, 24, 102-16). More recently, many Western-trained professionals have been recruited to the new public and private sector agencies established in the mid-2000s. These professionals have been advocating context-sensitive design as global best practice, instead of the conventional, narrower focus on operational and 'engineering' aspects of urban projects more typical of the Middle East region. This is a salient instance of the multi-cultural character of the stakeholder ecosystem in Abu Dhabi at work.

There are some examples of architectural modernism in Abu Dhabi from the 1960s-80s, which have provided an appropriate response to local cultural and climatic conditions (Damluji, 2006). It is important to recognize this layer as part of the urban heritage, to complement and provide continuity to the more ancient, pre-Oil era sites and buildings, which are more readily accepted as heritage (while it is not as easy to see stakeholders do so for modern buildings). The scope for adaptive reuse of both types of heritage is as yet somewhat limited, due to factors such as the fragile physical nature of pre-Oil buildings and the substandard physical construction techniques of some early modern period buildings, not to mention the absence of a sufficient culture and industry supporting the idea. However, as more value is placed by the government, developers and the local community on the full range of heritage assets, it will be easier to develop methods of regenerating and integrating them within urban development.

\section{Specific Emirati Cases}

Two particular case studies from Abu Dhabi emirate with complex stakeholder relations are highlighted here to illustrate issues related to the role of urban heritage.

Firstly, the Abu Dhabi Bus Station can be examined as an example of conflicts that arise between the mandates of different agencies. A major urban landmark of modern architectural heritage in downtown Abu Dhabi, the Bus Station was designated for protection by ADACH/ TCA, but also scheduled for replacement with a new facility as part of the bus transportation development plans of the DoT (Figure 8, 9). At the time of the author's employment, negotiations between the two agencies were ongoing, with several rounds of correspondence and meetings that began 
Figure 10. Aerial view of Al Ain Oasis with Jebel Hafit mountain in the background (Abu Dhabi Urban Planning Council archive)

Figure 11. Evaluation mission sent by UNESCO World Heritage Center leading up to the inscription of $\mathrm{Al}$ Ain on the WH List (photo: E. Yıldırım, 2010) in relatively hostile and uncompromising tones and which evolved into more subtle discussions seeking acceptable design solutions, but still failed to reach a full agreement. The debate took a turn on the side of preservation, as it was raised to the level of the Abu Dhabi Executive Council, and various briefings on the significance of the station urged key transportation officials to re-consider the redevelopment scheme. Recent news indicate that the preservation of the original landmark was finally favored (Chabbi, 2014); the initiative started in 2010 by TCA for the study and conservation of Modern Buildings in Abu Dhabi, which was presented to the emirate leadership in 2012 as a larger scheme also including the Bus Station, appears instrumental in this positive outcome. It has also been promising to see in this regard that the UAE Pavillion in the 2014 Venice Architectural Biennale was devoted to the modern architecture of the country.

As the second case study, many issues related to stakeholder perceptions of heritage can also be observed in $\mathrm{Al}$ Ain. Considered the most authentic city within the emirate, the modern city of $\mathrm{Al}$ Ain has developed in juxtaposition with an ancient oasis landscape, which was inscribed as a UNESCO World Heritage Site (WHS) as the serial property of The Cultural Sites of Al Ain (Figures 10, 11). Al Ain Oasis, one of the components of the property, has been the subject of TCA's Al Ain Oasis Cultural Quarter Master Plan, aimed to connect the historic oasis with the surrounding urban fabric, and conserve it as a local environmental resource (Yıldırım and El Masri, 2010). The master planning efforts and the WHS nomination process were advanced through productive inter-agency coordination between TCA, UPC and Al Ain Municipality (AAM), which enabled the integration of the oasis master plan with the wider local plan, and to ensure coordination of the development control processes of each agency in and around the WHS areas. The AAM has supported some development restrictions by exercising the basic economic tool of plot reallocation. As additional restrictions arising from the WHS took effect in the property's buffer zones, reactions of local landowners and developers have also increased, revealing the need for more effective outreach to the local community to garner their support. With this realization, TCA partnered with AAM to develop a joint WHS Communication Strategy, which was in infant stages at the time of the author's employment (Figure 12). The WHS designation also seems to have triggered a shift in the tourism marketing policy of the former ADTA, and the integration of the cultural heritage and tourism agencies forming TCA
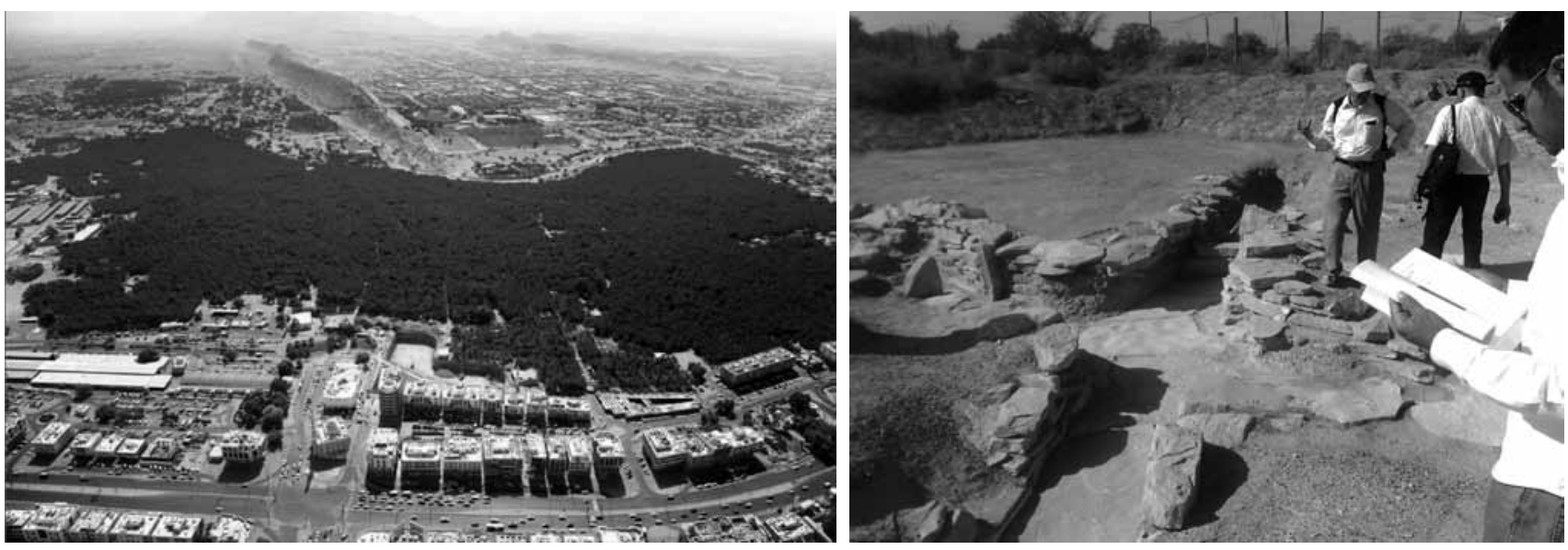

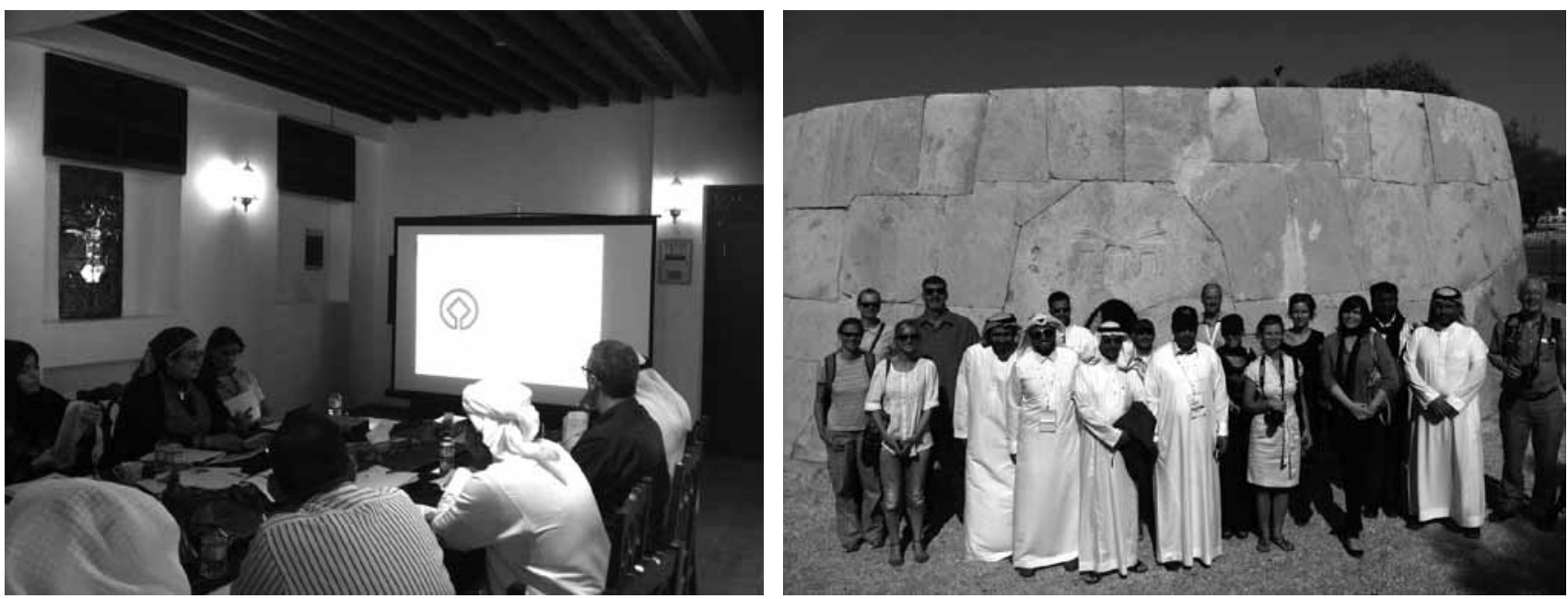

Figure 12. Meeting of the Communication Strategy Team for the Al Ain World Heritage Site, Al Aİn (photo: E. Yıldırım, 2012)

Figure 13. International tourism event delegation in The Cultural Sites of Al Ain World Heritage Site (photo: E. Ylldırım, 2012) is likely to support work on cultural tourism promotion in Al Ain (Figure 13).

\section{Conclusions on the Emirati Context}

The above observations and case studies suggest that although the urban heritage has not been immediately explicit in cities within Abu Dhabi Emirate, it is nonetheless gradually being recognized for its unique characteristics, created by a combination of factors special to this region and telling the particular story of the emirate's development. With the maturing of public organizations, legislation and capacity building with qualified local and expatriate professionals to support its conservation, the development of its awareness among interested social groups, and perhaps most importantly its prioritization by the emirate leadership, the urban heritage is slowly acquiring a more prominent role in the urban development context of Abu Dhabi.

\section{COMPARATIVE DISCUSSION}

In evaluating the contexts of Turkey and the UAE, one can say that while the two countries have quite different histories and socio-political situations, they are both affected by and take part, in their own ways, in the developments occurring around the world, in terms of stakeholders and the role of urban heritage.

The most important thread that one observes to tie the countries' experiences together is the general process of modernization, although each is at a different stage along this trajectory and have not necessarily followed the same sequence of steps to arrive where they are. In particular, both societies being predominantly Muslim and Middle Eastern, with elements of traditional and conservative cultures, the Emirati population can be said to be facing, since the late $20^{\text {th }}$ century, some of the same key issues of modern life that the Turkish population was facing in the early $20^{\text {th }}$ century with the establishment of the modern republic, and partly in the late Ottoman period. This has spatial dimensions, such as the move from large traditional houses for extended families to high-rise apartments for nuclear families, and social dimensions, such as the development of participatory governance in planning and the establishment of civil institutions in regulating urban development. 
In terms of shaping stakeholder values and attitudes toward the role of urban heritage, modernization overlaps largely with democratization, and the evolution from conservative to progressive policy tools. Referring to the range of tools for preserving the built heritage as formulated by Schuster et al (1997) in a sequence of most to least conservative, i.e. from ownership and operation, to regulation, incentives, property rights and information, Turkey's mid-2000s legislative and administrative reforms enabled more advances along this line. However, tools such as plot reallocations to enable the transfer of development rights are also in use by Abu Dhabi's municipalities. In terms of the shift from top-down, government-controlled governance system toward multi-actor settings, Turkey adopted more of these changes in the mid-2000s, although some multi-actor processes such as public-private partnerships can be found in the UAE as well. The federal government of the Emirates supports a decentralized governance structure more easily than a unitary state like Turkey, but local devolution in Turkey was also in process, notably in relation to European Union accession.

While modernization and democratization are the general long-term trends that are declared officially and realized albeit slowly, the cultural characteristics of the societies in question need to be kept in mind, as contradictory developments also occur that can cause irretrievable losses, making this trajectory uneven, perhaps even torturous. The current situation in Turkey with new legislation undermining democratization is a symptom of this uneven progress. In both countries, beside the forwardlooking aspirations, there is still an authoritarian governance culture, where top-down government has more weight and civil society is relatively less established, or at least not institutionalized sufficiently to ensure the power balance. The economically productive role of heritage is still likely to overshadow other components of the active role such as the public good and authenticity, while a more holistic and sustainable perception of this role is dependent on the goodwill of a powerful government (e.g. the Abu Dhabi Bus Station). The international literature on the subject, which still originates largely in Western contexts, needs to be refined and adapted to consider these local governance dynamics and adjust expectations accordingly.

In Turkey, concepts of urban heritage and its integration with the planning process have long been in evolution, resulting in more mature institutions and complex administrative systems. The much more substantial stock of built heritage to deal with, the economic dynamism in cities and the scarcity of financial resources in proportion to the size of the heritage stock, lend certain challenges to the effort of conservation. In the UAE, the drive to catch up and excel on the global stage, and the exposure to international best practice ideas brought by expatriate professionals, enable a potentially faster adoption of progressive models, though their true digestion and internalizing by the local community naturally requires more time. Conversely for the UAE, time is short, but financial resources plenty. Also distinguishing the UAE are the multicultural collisions of professional and cultural practices, and the unusual, post-modern combinations that result from it. In both countries, however, the fact that promoting the role of heritage in the face of development and urban life in general involves a struggle, is not so different. No matter how much wealth there may be, the action of engaging with urban heritage depends on the interest and will by those stakeholders with the power to allocate and mobilize resources. Both countries thus prove themselves to be part of the same global community, 
where the future of urban conservation requires stakeholders to value and harbor a positive attitude toward the urban heritage.

\section{ACKNOWLEDGMENTS}

For their support throughout the preparation of this article and its formative experiences, the author sincerely thanks Ms. Amel Chabbi, Assist. Prof. Dr. Betül Duman, Assoc. Prof. Dr. Ela Babalık Sutcliffe, Prof. Dr. Emel Göksu, Assoc. Prof. Dr. Emre Madran, Mr. Eric Wilson, Dr. Hossam Mahdy, Asst. Prof. Mevlüde Kaptı, Dr. Sami El-Masri, Mr. Sanjay Trivedi and Dr. Simone Ricca.

\section{BIBLIOGRAPHY}

ALLIES AND MORRISON, M\&N (2011) Building Knowledge Forum, 20 November 2011, unpublished notes, Abu Dhabi.

AVRAMI, E., MASON, R., DE LA TORRE, M. (2000) Values and Heritage Conservation, The Getty Conservation Institute, Los Angeles.

CHABBI, A. (2014) Personal Correspondence, June 2014.

DAILY BREEZE (2012) Historic preservation benefits touted The Daily Breeze (May 8, 2012). [http://www.dailybreeze.com/ci20576477] Access date (12.05.2012).

DAMLUJI, S. S. (2006) The Architecture of the United Arab Emirates, Garnet Publishing, Reading.

DEVECI, H. (2013) New Pursuits in Turkish Local Government, Centre for Policy and Research on Turkey Portal, 25 February 2013 [http:// researchturkey.org/new-pursuits-in-turkish-local-government/] Access date (11.12.2014)

DİNÇER, İ. (2011) Seçmenin kritik tercihi: “Daha çok demokrasi"mi “daha çok proje"mi? Mimarlık Gündem, Mimarlık, (360) 10-1.

DINLER, M. (2013), Impact Assessment of Major Urban Interventions on the Cultural Heritage of Fener and Balat Districts, unpublished master thesis, Middle East Technical University, Graduate School of Natural and Applied Sciences, Ankara.

DRIVERS JONAS (2011) Heritage Works: The use of historic buildings in regeneration, A toolkit of good practice. [ http://www.english-heritage. org.uk/content/imported-docs/f-j/heritageworks.pdf] Access date (09.08.2011).

FEILDEN, B., JOKILEHTO, J. (1993) Management Guidelines for World Heritage Sites, ICCROM, Rome.

GAZİANTEP BÜYÜKŞEHİR BELEDİYESİ (2008) Aylık Bülten, Kasım 2008, Gaziantep

GETTY CONSERVATION INSTITUTE (2011) Conservation Perspectives 26(2) ('Historic Cities' issue), Getty Conservation Institute.

GOVERNMENT OF ABU DHABI (2007) Abu Dhabi 2030 Economic Policy Agenda 2007-08.

ICOMOS (2011) $17^{\text {th }}$ ICOMOS General Assembly and Scientific Symposium: Heritage, a driver of development, Speakers and Speeches (27 November- 2 December 2011), ICOMOS, Paris. 
KARAMAN, Y.İ. (2011) İl özel idarelerinin kurumsallaşma süreci (Batman Il Özel İdaresi), yayınlanmamış yüksek lisans tezi, Ankara Üniversitesi Sosyal Bilimler Enstitüsü, Ankara University, Ankara. [http:// acikarsiv.ankara.edu.tr/browse/6218/] Access date (23.05.2012).

KELEŞ, R. (2014) Anakent Yönetimlerini Yeniden Düzenleyen Yasa Ne Getirdi, Ne Götürdü? Geçmişten Geleceğe Yerel Kimlik, (7) 28-33.

KHALEEJ TIMES (2012) New tourism and culture authority for Abu Dhabi, Khaleej Times, 10 February 2012. [http://www.khaleejtimes. com/DisplayArticle11.asp?xfile=data/theuae/2012/February/theuae February258.xml\&section=theuae] Access date (11.12.2014).

LANDORF, C. (2011) Heritage and the Governance Agenda: Can historic urban environments survive the devolution of development control? 17th ICOMOS General Assembly and Scientific Symposium: Heritage, a driver of development, Speakers and Speeches (27 November- 2 December 2011), ICOMOS, Paris; 98.

MADRAN, E. (2005) Kültür ve Tabiat varlıklarını Koruma Mevzuatındaki son düzenlemeler, Korumada 50 Yıl Sempozyumu Bildiriler Kitabl, Mimar Sinan Güzel Sanatlar Üniversitesi, 17-18 Kasım 2005, MSGSÜ, İstanbul; 245-55.

MADRAN, E. (2013) Namık Kemal (Saraçoğlu) Mahallesi (NKM) Önemi, Değerleri, Solfasol, 2(23) 12-3.

OKOTH, S. (2014) Public Policy Making Process in the United Arab Emirates, Public Administration and Policy in the Middle East, ed. A. D., Springer-Verlag, New York; 262-80.

ÖZDEMIR, D., ed. (2010) Kentsel Dönüşümde Politika, Mevzuat, Uygulama: Avrupa Deneyimi, İstanbul Uygulamalar, Nobel, Ankara.

ROJAS, E. (2011) Sustainable Preservation of the Urban Heritage, Conservation Perspectives, Getty Conservation Institute, 26(2) 10-2.

ROYAL INSTITUTE OF CHARTERED SURVEYORS (2011) Heritage: A Catalyst for Regeneration, Modus, May 2011 (The 'Heritage' issue), Royal Institute of Chartered Surveyors, London, 46.

RYPKEMA, D., CHEONG, C., (2011a) Measurements and Indicators of Heritage as Driver of Development. 17th ICOMOS General Assembly and Scientific Symposium: Heritage, a driver of development, Speakers and Speeches (27 November- 2 December 2011), ICOMOS, Paris; 148.

RYPKEMA, D., CHEONG, C. (2011b) Heritage Conservation: The Real Sustainable Development. 17th ICOMOS General Assembly and Scientific Symposium: Heritage, a driver of development, Speakers and Speeches (27 November- 2 December 2011), ICOMOS, Paris; 149.

SCHUSTER, J. M., DE MONCHAUX, J., RILEY, C. A., eds. (1997) Preserving the built heritage: Tools for implementation, University Press of New England, Hannover.

SHIPLEY, R., REEVE, A. (2011) Does Investment in the Built Fabric of Historic Towns Drive Economic Recovery? 17th ICOMOS General Assembly and Scientific Symposium: Heritage, a driver of development, Speakers and Speeches (27 November- 2 December 2011), ICOMOS, Paris; 157. 
SIRAVO, F. (2011) Conservation Planning: the Road Less Traveled. Conservation Perspectives 26(2) 4-9.

ŞAHİN GÜÇHAN, N, KURUL, E. (2005) 2003-2005 Döneminde Gerçekleştirilen Yeni Yasal Düzenlemeler ve Koruma Alanına Etkileri: Bir Ön Değerlendirme, Korumada 50 Yal Sempozyumu Bildiriler Kitabı, Mimar Sinan Güzel Sanatlar Üniversitesi, 17-18 Kasım 2005; 159-69.

ŞAHIN GÜÇHAN, N, KURUL, E. (2009) A history of the development of urban and architectural conservation in Turkey: from the mid-19th century until 2004, METU Journal of the Faculty of Architecture, 26(2) 19-44.

THROSBY, D. (2002) Cultural Capital and Sustainability Concepts in the Economics of Cultural Heritage, Assessing the Values of Cultural Heritage, ed. M. De La Torre, Getty Conservation Institute, Los Angeles; 101-18.

YILDIRIM, E. (2009) Demokratikleşen Koruma ve Planlama Üzerine Düşünceler, Mimarlar Odası Ankara Şubesi Bülteni, Dosya 14(1) 69-72.

YILDIRIM, E., EL MASRI, S. (2010) Master planning for heritage conservation in Al Ain Oasis, UAE, 46th ISOCARP Congress, Nairobi, Kenya, Proceedings (September 19-23, 2010). [http://www.isocarp.net/ projects/casestudies/cases/csinfo.asp?ID=1705] Access date (02.09. 2011).

TURKISH PRIME MINISTRY, DIRECTORATE GENERAL OF FOUNDATIONS, Official Website. [http://www.vgm.gov.tr/index. aspx?Dil=EN] Access date (23.05.2012).

REPUBLIC OF TURKEY, MINISTRY OF CULTURE AND TOURISM, Official Website. [http://www.kultur.gov.tr/EN/anasayfa/2-0/20120524.html] Access date (23.05.2012).

TURKISH PRIME MINISTRY, DIRECTORATE GENERAL OF LEGISLATION DEVELOPMENT AND PUBLICATION, Official Gazette. [http://www.resmigazete.gov.tr/default.aspx] Various access dates (2012-2014).

UNESCO, National Cultural Heritage Laws Portal, [UNESCO/ Culture/ National Laws/ Turkey] Access date (08.12.2014).

Alınd1: 19.09.2013; Son Metin: 27.02.2015

Anahtar Sözcükler: Paydaşlar; kentsel koruma; küreselleşme; Türkiye; Birleşik Arap Emirlikleri.

\section{KENTSEL KORUMANIN DEĞISSEN ROLÜ: TÜRKIYYE VE BİRLEŞİK ARAP EMİRLIKKLERI'NDEKI PAYDAŞLARIN ALGISI VE YÖNETISŞIM}

Bu makalede, kültür mirasının kent yaşamındaki değişen rolü ile ilgili paydaşların kültür mirasına karşı tutumları arasındaki ilişkinin ortaya konması amaçlanmıştır. Konu, yazarın 2008-11 yıllarında hazırladığ 1 Kentsel Koruma Projelerinde Aktörlerin Örgütlenmesi başlıklı doktora tez çalışması kapsamında Türkiye içinden seçilmiş bazı kentler ile yazarın 2008-12 yıllarında çalıştığı, Birleşik Arap Emirlikleri'nin Abu Dabi Emirliğindeki yerleşimler çerçevesinde ele alınmıştır. Bu karşılaştırmalı incelemenin amacı, bu iki farklı ülke arasında gözlenebilecek benzer 
olguları ve her bir ülkeye özgü özgül durumları saptamak olmuştur. Küreselleşen dünya ve mesleki ağlar göz önünde bulundurulduğunda, bu tür karşılaştırmaların, planlama ve mimari koruma pratiğinin çeşitli bağlamları arasında mümkün olabilecek çapraz etkilenmelerin kapsamını anlamaya yardımcı olacağı düşünülmektedir.

Yukarıda anılan araştırma ve uygulama deneyimlerinden ortaya çıkan sonuç, kentlerin planlaması, gelişimi ve kamusal yaşamında kültür mirasının oynayabileceği rolün, koruma sürecinde yer alan paydaşların tutumlarıyla ve süreçte oynadıkları rollerle yakından ilişkili olduğu yönündedir. Kültür mirasının kent yaşamında aktif bir rol oynayabilmesi veya imar baskıları ile çağdaş sosyal talepler karşısında özgünlüğünü koruyabilmesi, her biri kendi farklı çıkarları ve kapasiteleri olan çeşitli paydaşlar arasındaki müzakerelerin sonucuna göre şekillenmektedir. Türkiye ve Birleşik Arap Emirlikleri'ndeki gelişmeler gözlemlendiğinde, iki ülkenin farklı tarihçelerine ve sosyo-politik yapılarına karşın, ikisinin de kültür mirasının rolu ve paydaşlar bakımından dünyadaki gelişmelerden etkilendikleri ve bunlara dahil oldukları söylenebilir. İki ülke deneyiminin en önemli ortak paydası, genel bir modernleşme sürecidir, ancak sürecin farklı aşamalarında durmakta ve farklı adımlardan geçerek ilerlemektedirler. Bu toplumların geleneksel ve muhafazakar kültürel yapıları göz önüne alınarak, izlendiği iddia edilen ve uzun vadede yavaş da olsa gerçekleşen genel eğilimin modernleşme ve demokratikleşme olmasına karşın, bu pürüzsüz olmayan, hatta çetin ve sancılı sayılacak süreçte ilerlenirken dönem dönem, tamiri mümkün olmayan kayıplara yol açan geri adımlar da atılabilmektedir.

Her ülkede de, kültür mirasının imar ve genel kentsel dinamikler karşısındaki rolünü desteklemek için mücadele verilmesi gerektiği bir diğer ortak noktadır. Ülkelerin ekonomik güçleri ne olursa olsun, kültür mirasını korumak, kaynakları ayırma gücüne sahip paydaşların verdiği değere, gösterdiği ilgi ve siyasi iradeye bağlıdır ve bu gerçek dünyanın her yerinde geçerli görünmektedir.

AYŞE EGE YILDIRIM; B.CP, MA, PhD.

Is an urban planner specializing in heritage conservation, particularly on its governance aspects. After five years working in the Abu Dhabi Culture \& Heritage Authority, she relocated to İstanbul in 2012, was research fellow at Koç University during 2013-14 and has been consulting various clients on site management since 2014, including Mudurnu Municipality, Eyüp Municipality (with Bilgi University), the Aspendos Project and the Boğsak Archaeological Survey. egey@yahoo.com, ege@aegeyildirim.com 